\section{Feline companions and demography}

To the Editor: In A Moveable Feast by Ernest Hemingway, the author goes to visit Gertrude Stein and, sitting downstairs, hears from above the following by Ms Stein: 'Don't, pussy. Don't. Don't, please don't. I'll do everything, pussy, pussy, but please don't do it. Please don't. Please don't, pussy.' Hemingway immediately leaves, having said to a servant: 'What a shame.' Gertrude Stein might have said that to her cat jumping onto a table and walking upon some manuscripts. Admittedly, Hemingway mentioned that he had heard another person speaking too. Looking at portraits of Gertrude Stein and her companion, it is clear they were indeed lesbian; but it was also civil heroism: being well-known figures, they exposed themselves to moralising and mockery for popularising the simple idea that, in the age of upcoming overpopulation, sexual minorities voluntarily remove themselves from the sexual market and child production, which is of significance also for ethnic minorities. It is a well-known fact that ethnic stability of a society is a precondition for its political stability, and that quantitative ethnic transformations can cause social tensions. Therefore, another hypothesis appears to be probable: Ms Stein, being aware of Mr Hemingway's visit, had played this scene to move him towards writing about it, which he in fact did, to support the belief in her homosexuality. It could be added that

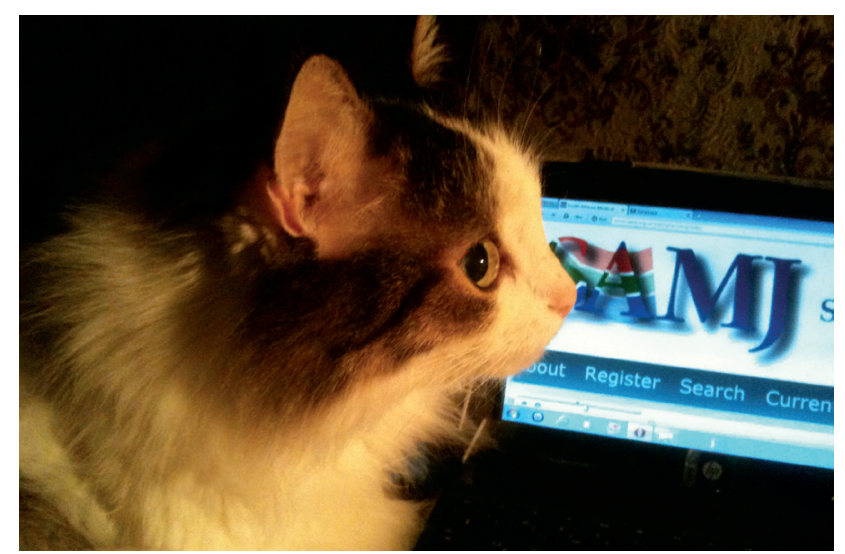

Fig. 1. Barsik, one of the author's cats, takes an interest in the SAMJ. potential solutions to the overpopulation problem require a revision of some ethical clichés, e.g. the negative attitude to sexual minorities, although, probably, children and young adults should be protected from their direct influence; and propagation of a novel ethical principle: no population group, whether ethnic or confessional, on a national or on an international scale, should obtain any political or other advantages merely because of its numerical size. On the contrary, those who have had many children should logically live in more confined conditions.

High fertility was propagandised in the age of global conflicts and the Cold War to replenish military and manpower resources; while birth control and family planning have been obfuscated by conflicting national and international interests, because population growth has sometimes been regarded as a tool helping to achieve sovereignty and economic advance. A concluding point is that globalised mankind should not only eliminate the motives for high fertility, but also protect those who voluntarily abstain from participating in the procreative competition. Cats can help us in this objective. It is written in the epigraph to the editorial[ ${ }^{[1]}$ about dogs: '.. he renders services that have made him man's best friend.' This is true; but if dogs are friends, cats are not only our companions but also children, grandchildren and loved ones (Fig. 1), which is increasingly important in view of demographic problems ${ }^{[2]}$ and gender imbalances. ${ }^{[3]}$ There is a short essay by Gertrude Stein on a related topic. ${ }^{[4]}$

\section{Sergei Jargin}

Peoples' Friendship University of Russia, Moscow, Russia sjargin@hotmail.com

\footnotetext{
1. Seggie J. Our canine carers. S Afr Med J 2013;103(3):128-129.

2. Jargin S. Ethical challenges in an age of overpopulation. S Afr Med J 2010;100(11):694.

3. Jargin S. Where have all the flowers gone? S Afr Med J 2011;101(8):494

4. Stein G. Reflection on the Atomic Bomb. New Haven, USA: Yale Poetry Review, December 1947.

. Stein G. Reflection on the Atomic Bomb. New Haven, USA: Yale Poetry Review, D
http://writing.upenn.edu/ afilreis/88/stein-atom-bomb.html(accessed 1 March 2013).
}

S Afr Med J 2013;103(6):357. DOI: 10.7196/SAMJ.6851 